\title{
“A NOTE ON NATURAL ADSORBANT (MORINGA OLEIFERA) AS ANTIMICROBIAL AGENT IN WATER PURIFICATION"
}

\author{
S.V.Maruti Prasad ${ }^{1}$, H.Ramamohan ${ }^{2}$, B.SrinivasaRao ${ }^{3}$ \\ ${ }^{I}$ Asst. Professor of Chemistry, Department of Basic Science \& Humanities, Aditya Institute of Technology \\ \&Management Tekkali Srikakulam District, Andhra Pradesh, India. \\ ${ }^{2}$ Asst. Professor of Environmental Studies, Department of Basic Science \& Humanities, Aditya Institute of Technology \\ \& Management, Tekkali, Srikakulam District, Andhra Pradesh, India. \\ ${ }^{3}$ Professor of Physics, Department of Basic Science \& Humanities, Aditya Institute of Technology \& Management, \\ Tekkali Srikakulam District, Andhra Pradesh, India.
}

\begin{abstract}
The efficacy of Moringa Oleifera on water purification, especially, antimicrobial activity was studied in this paper by adding different concentrations to turbid water sample. Microbe reduction in water is achievable using Moringa Oleifera even when the coagulation process is slow but proper Moringa Oleifera Seed dosage along with disinfectant like chlorine will produce better results.
\end{abstract}

Keywords: MoringaOleifera, Alum, Antimicrobial efficiency, Raw water purification, Dosage, Coagulation.

\section{INTRODUCTION}

Water is one of the fundamental requirements of life and any undesired addition of unwanted materials leads to contamination and makes it unfit for human usage. Presently there are no appropriate low cost methods for removal of water contaminants. In rural areas like study area, people live in extreme poverty are drinking highly turbid and microbiologically contaminated water, due to limited clean and safe water sources.

The coagulant activity of MoringaOleifera Seeds is widely known and applied in water treatment at house level in rural $\operatorname{areas}^{[2]}$. However, there are constraints in the use of chemical coagulants (alum) such as, scarcity of foreign currency for importation and inadequate supply of chemicals. Although alum is most commonly used coagulant in developing countries, its presence in drinking water develops some neurological diseases. Hence, there is a need to develop and to meet cost effective and also environmentally friendly coagulants like MoringaOleifera ${ }^{[9]}$.

MoringaOleifera is most widely cultivated species of a monogeneric family native tree of Sub-Himalayan parts of North West India, Pakistan and Afghanistan. Earlier studies have found MoringaOleifera to be non-toxic and recommended it for the use as a coagulant ${ }^{[4]}$. In this a preliminary study was done, to check the efficiency of MoringaOliefera as Antimicrobial agent for the water of this study area.

\section{MATERIALS AND METHODS}

MoringaOleifera seed powder were obtained from Tekkali residential area, A.P., India. The seed coats were removed to get the kernels. The kernels were dried and ground to powder. Different concentrations of Moringa Seed solutions were made by diluting $1 \mathrm{gr}, 1.5 \mathrm{gr}$ and $2 \mathrm{gr}$ of the Moringa Seed Powder into $100 \mathrm{ml}$ of distilled water to obtain $1 \%$, $1.5 \%$ and $2 \%$ concentrations of the solutions. The solutions were shaken properly for 1 minute to extract and activate the antimicrobial properties in the seed powder. Each of the concentrations was poured into one litre of water sample and stirred for 2 minutes. After undisturbed for 6 hours, 100ml was taken for the use of analysis. For comparison sake alum coagulant was prepared by adding $1 \mathrm{gr}$. of alum in $100 \mathrm{ml}$. of distilled water and shake for 60 seconds. The solution was then added to 1 litre of the water sample. The microbial analysis was performed to check the microbiological quality of water samples. These tests analyses total mesophilic bacteria count, total mesophilic fungal count and total coliform bacterial before and after treatment with MoringaOleifera into the water sample.

Table-1: Microbial analysis of the water sample before treatment with M.O.

\begin{tabular}{|l|l|l|}
\hline $\begin{array}{l}\text { SI.N } \\
\text { o. }\end{array}$ & Microbial counts & $\begin{array}{l}\text { Number of } \\
\text { colonies }\end{array}$ \\
\hline 1 & Total mesophilic bacteria & $200 \times 10^{2} \mathrm{CFU} / \mathrm{ml}$ \\
\hline 2 & Total mesophilic fungi & $60 \times 10^{2} \mathrm{CFU} / \mathrm{ml}$ \\
\hline 3 & Total coliform & $25 \times 10^{2} \mathrm{MPN} / \mathrm{ml}$ \\
\hline
\end{tabular}




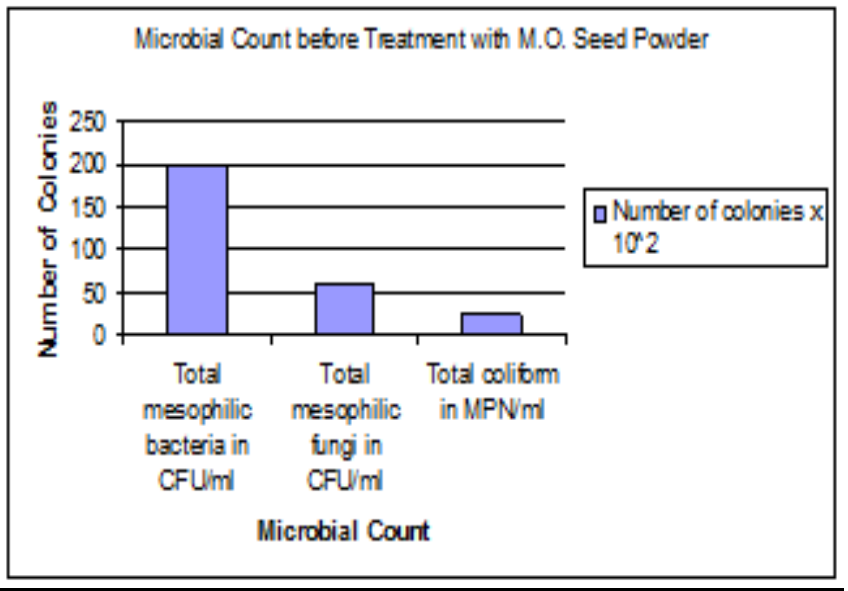

Graph-1: Microbial Count before Treatment with M.O.Seed Powder

Table-2: Microbial analysis of the water sample after treatment with M.O. seed solution at different concentrations

\begin{tabular}{|l|l|l|l|l|}
\hline $\begin{array}{l}\text { Sl. } \\
\text { No. }\end{array}$ & $\begin{array}{l}\text { Concentra- } \\
\text { tion of } \\
\text { MoringaOl } \\
\text { eifera } \\
\text { Seeds in \% }\end{array}$ & $\begin{array}{l}\text { Total } \\
\text { Mesophilic } \\
\text { bacteria in } \\
\text { CFU/ml }\end{array}$ & $\begin{array}{l}\text { Total } \\
\text { mesophilic } \\
\text { fungi in } \\
\text { CFU/ml }\end{array}$ & $\begin{array}{l}\text { Total } \\
\text { coliform } \\
\text { in } \\
\text { MPN/ml }\end{array}$ \\
\hline 1 & 1.0 & $20 \times 10^{2}$ & $10 \times 10^{2}$ & $10 \times 10^{2}$ \\
\hline 2 & 1.5 & $18 \times 10^{2}$ & No growth & $06 \times 10^{2}$ \\
\hline 3 & 2.0 & $05 \times 10^{2}$ & No growth & $03 \times 10^{2}$ \\
\hline
\end{tabular}

Series 1: Total MesophilicBateria in CFU/ml.

Series 2: Total Mesophilic Fungi in CFU/ml.

Series 3: Total coliform in MPN/ml.

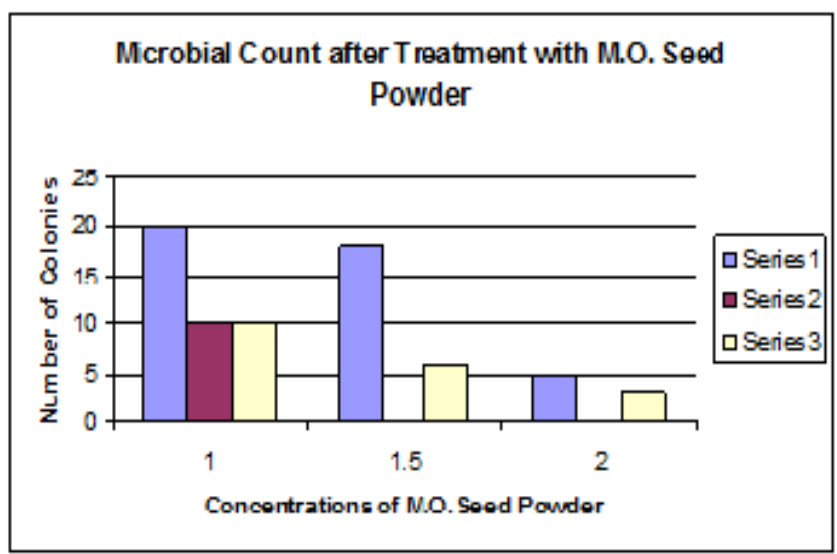

Graph-2: Microbial Count after Treatment with M.O.Seed Powder

Table-3: Physicochemical analysis of the water sample before treatment with M.O.

\begin{tabular}{|l|l|l|}
\hline Sl.No. & $\begin{array}{l}\text { Physicochemical } \\
\text { parameters }\end{array}$ & $\begin{array}{l}\text { Concentration } \\
\text { value }\end{array}$ \\
\hline 1 & TDS (Total Dissolved Salts) & $45 \mathrm{ppm}$ \\
\hline 2 & TSS (Total suspended solids) & $0.7 \mathrm{gr} . / \mathrm{ml}$ \\
\hline 3 & Conductivity & $100.2 \square \mathrm{s}$ \\
\hline 4 & Turbidity & $28 \mathrm{NTU}$ \\
\hline
\end{tabular}

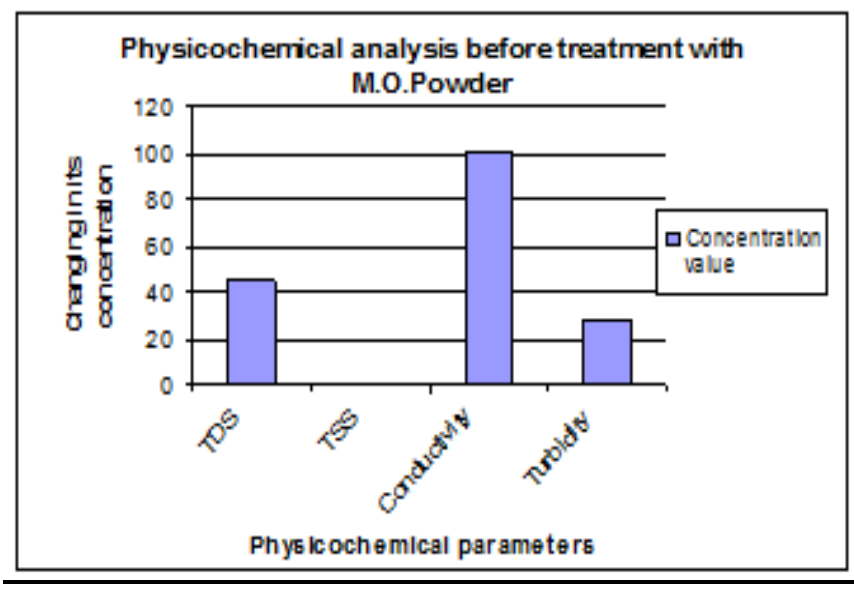

Graph-3: Physicochemical analysis before treatment With M.O.Powder

Table-4: Physicochemical analysis of the water sample after treatment with M.O. and alum

\begin{tabular}{|l|l|l|l|}
\hline \multirow{2}{*}{$\begin{array}{l}\text { Sl. } \\
\text { N }\end{array}$} & Physicochemical & \multicolumn{3}{l|}{$\begin{array}{l}\text { Concentration } \\
\text { value }\end{array}$} \\
\cline { 3 - 4 } parameters & $\begin{array}{l}\text { Moringa } \\
\text { Oleifera }\end{array}$ & Alum \\
\hline 1 & TDS (Total Dissolved Salts) & $40 \mathrm{ppm}$ & -- \\
\hline 2 & TSS (Total suspended solids) & $0.2 \mathrm{gr} / \mathrm{ml}$ & -- \\
\hline 3 & Conductivity & $98.2 \square \mathrm{s}$ & -- \\
\hline 4 & Turbidity & $18 \mathrm{NTU}$ & $7 \mathrm{NTU}$ \\
\hline
\end{tabular}

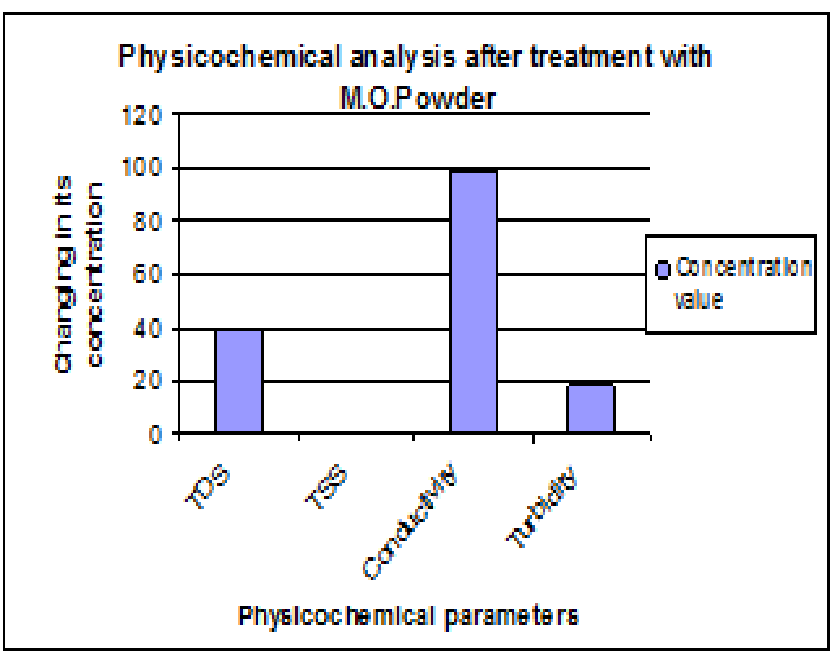

Graph-4: Physicochemical analysis after treatment with M.O. Powder

Table-5: Microbial assessment of the sample with $1 \%$ by weight concentration of alum as a coagulant.

\begin{tabular}{|l|l|l|}
\hline Sl.No. & Microbial count & No. of colonies \\
\hline 1 & Total mesophilic bacteria & $180 \times 10^{2}$ \\
\hline 2 & Total mesophilic fungi & $47 \times 10^{2}$ \\
\hline 3 & Total coliform & $13 \times 10^{2}$ \\
\hline
\end{tabular}




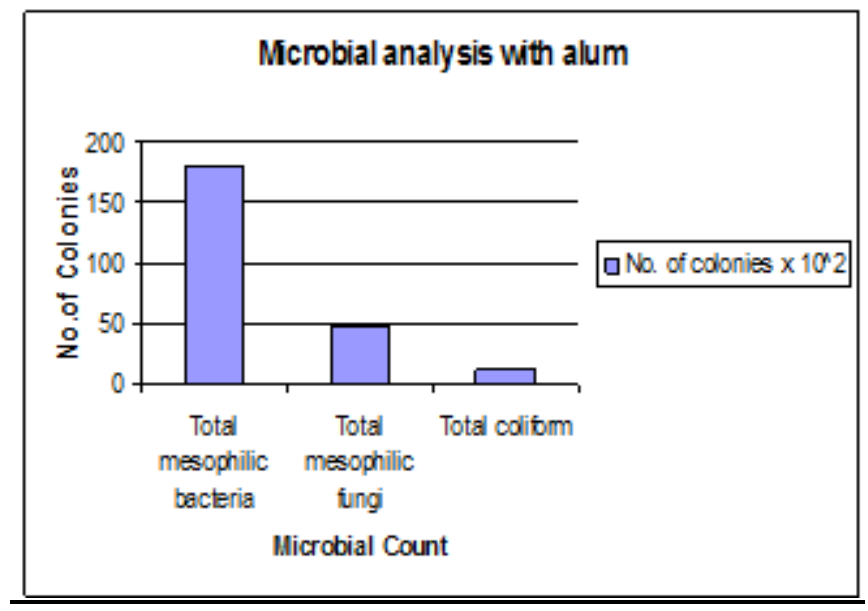

Graph-5: Microbial analysis with alum

\section{RESULTS}

The microbial assessment of raw water sample before treatment indicated that the water sample contains $200 \times 10^{2}$ $\mathrm{CFU} / \mathrm{ml}$ of mesophilic bacteria, $60 \times 10^{2} \mathrm{CFU} / \mathrm{ml}$ of mesophilic fungi and $25 \times 10^{2} \mathrm{MPN} / \mathrm{ml}$ of Coliform bacteria (Table-1). The physicochemical analysis shows that the water sample has TDS of $45 \mathrm{ppm}$, TSS of $0.7 \mathrm{gr} . / \mathrm{ml}$, Conductivity of $100.2 \square \mathrm{s}$ and turbidity of 28NTU, as indicated in Table-3.The above observations have been shown graphically in Graph-1 and Graph-3 respectively.

Table-2 depicts the results for microbial analysis of water sample with MoringaOleifera at different concentrations. The data indicates that the microbial load in the water sample reduced considerably as the concentrations are increased from 1 to $2 \%^{[1][3]}$. Table-5 gives microbial assessment of the sample with $1 \%$ by weight of alum.

The results of physicochemical analysis of water sample after treatment with $1 \%(1 \mathrm{gr} / 100 \mathrm{ml})$ by weight concentration of MoringaOleifera and alum solution indicates that the turbidity is reduced to 18 NTU and 7 NTU respectively ${ }^{[1][3]}$ (Table-4), but no significant changes in other parameters. This may be because of floc formation size, when MoringaOleifera was added, its seed coagulant proteins were tiny and light thus settled so slowly whereas the flocs formed by the alum coagulant were large enough and sedimentation rate was higher and faster ${ }^{[6]}$.

\section{DISCUSSIONS}

The data obtained from microbial analysis of water sample before treatment with Moringa Seed solution (Table-1) indicates that the total mesophilic bacteria and total mesophilic fungi concentrations are as high as $200 \times 10^{2}$ $\mathrm{CFU} / \mathrm{ml}$ and $60 \times 10^{2} \mathrm{CFU} / \mathrm{ml}$ respectively. The total fecal coliform bacteria were found to be $25 \times 10^{2} \mathrm{MPN} / \mathrm{ml}$, suggesting the presence of pathogens in the water samples. This data thus indicate how unsafe the raw water is for human consumption as it could cause gastrointestinal diseases. The presence of mesophilic fungi in the water supports this.
However, treatment of water with MoringaOleifera seed solutions at different concentrations reduces in microbial counts in water $(\text { Table- } 2)^{[6]}$. The observations have been shown graphically in Graph No.2.

At $1 \%(1 \mathrm{gr} / 100 \mathrm{ml})$ concentration of the Moringa Solution, total mesophilic bacteria, total mesophilic fungi and total coliform bacteria count were reduced to $20 \times 10^{2} \mathrm{CFU} / \mathrm{ml}$, $10 \times 10^{2} \mathrm{CFU} / \mathrm{ml}, 10 \times 10^{2} \mathrm{MPN} / \mathrm{ml}$.At $1.5 \%(1.5 \mathrm{gr} / 100 \mathrm{ml})$ Moringa concentration, total mesophilic bacteria and total coliform bacteria count were reduced to $18 \times 10^{2} \mathrm{CFU} / \mathrm{ml}$, and $6 \times 10^{2} \mathrm{MPN} / \mathrm{ml}$ respectively, where total mesophilic fungi showed no growth. At $2 \%$ concentrations of the Moringa solution, total mesophilic bacteria and total coliform bacterial count were reduced to $5 \times 10^{2} \mathrm{CFU} / \mathrm{ml}$, and $3 \times 10^{2} \mathrm{MPN} / \mathrm{ml}$ respectively where total mesophilic fungi showed no growth. Also coagulating the solid matter in water will also removes a good portion.

The reduction observed in bacterial population of raw water treated with MoringaOleifera can be attributed to an antibacterial properties of the bio-active ingredients.

These encouraging findings support the recommendation of MoringaOleiferawhich is a cheap and easy alternative for purifying water, especially in remote areas of this study area.

MPN means total coliforms which are calculated quantitatively. The presence of coliforms indicates water is fecally contaminated and not safe for drinking purpose. Due to coliforms various water borne diseases occurred therefore MPN should be nil for drinking water and other purposes.

MPN during present study was observed beyond the limit of WHO standards ${ }^{[7]}$. After treatment, MPN/ml coliform was decreased as increased dose of M.O. Powder. MPN found in the range $10 \times 10^{2} \mathrm{MPN} / \mathrm{ml}-3 \times 10^{2} \mathrm{MPN} / \mathrm{ml}$ to all samples after the treatment which indicates above the limits of WHO standards ${ }^{[7]}$. The presence of MPN gives direct proof of dangerous impurities in water and the treated samples are not safe for drinking purpose. Addition of another disinfectant like chlorine alongwith the seed powder which may give MPN zero.

\section{CONCLUSIONS}

This study successfully revealed that MoringaOleifera possess antimicrobial properties against mesophilic bacteria, mesophilicfungi. These extracts could be promising antimicrobial agents with potential applications in controlling bacteria which causes diseases. M.Oleifera can be cultivated very cheaply at household levels which is to be encouraged among rural populations. The MPN test had shown positive which indicates fecal contamination. Higher doses of Moringa Oleifera alongwith another disinfectant like chlorine may give best results and the water may be used for drinking purpose. Moringa Oleifera seed is not giving toxic effect. It is ecofriendly and cheaper method of water treatment. Moringa seeds can be used in rural areas where no facilities are available for drinking water 
treatment. After treatment, the sludge settled at the bottom of tank, can be used as bio-fertilizers.

\section{REFERENCES}

[1] Bina B., Mehdinejad M. H., Gunnel Dalhammer, GunaRajarao, M. Nikaeen and H. Movahedian Attar, Effectiveness of Moringa Oleifera coagulant protein as natural coagulant and in removal of turbidity and bacteria from turbid waters, World Academy of Science, Engineering and Technology, 67, (2010)

[2] Folkard G. and Sutherland T., The use of Moringaoleifera as a natural coagulant for water and waste water treatment, Department of engineering, University of Leicester, UK, (2001)

[3] Mangale S. M., Chonde S. G., Jadhav A. S., and Raut P. D. Study of Moringa oleifera (Drumstick) seed as natural Absorbent and Antimicrobial agent for River water treatment, J. Nat. Prod. Plant Resour., 2012, 2 (1):89-100.

[4] Olayemi A.B. and Alabi, R.O. Studies on traditional water purification using M. oleifera seed, African study monographs, 15, 101-109 (1994)

[5] Olsen A., Water research , 1987, 21 (3): 517-522.

[6] Suleyman A. Muyibi and Lilian M. Evison, "Moringaoleifera seeds for softening hard water", Department of Civil Engineering, University of Newcastle upon Tyne, Newcastle upon Tyne NEI 7RU, England, Wat. Res. 29(4), 1099-1105 (1994)

[7] WHO (2006). Guideline for drinking-water quality (electronic resources): incorporating first addendum. Vol. 1, Recommendations, 3rd edition Internet: http://www.who.int/water_sanitation_health/dwq/gd wq0506.pdf

[8] Madsen M., Schlundt J. and Omer E. F., Effect of water coagulation by seeds of $M$. oleiferaon bacterial concentration, J. Trop. Med. Hyg., 1, 90-109, (1987)

[9] Rebecca, H.S.U., Sharon, M., Arbainsyah, A.andLucienne, D. (2006): Moringaoleifera: medicinal and socio-economic uses. International Course on Economic Botany.National Herbarium Leiden, Netherlands. Pp. $2-6$.

\section{BIOGRAPHIES}

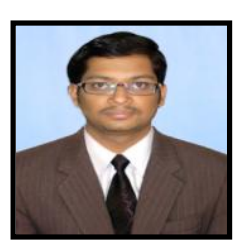

S.V.Maruti Prasad: 08 years teaching experience with 02 research papers on "Environmental Sciences". Acting as Board of Studies member for Department of Chemistry in AITAM, Tekkali. At present working as Asst. Professor of Chemistry, B.S.\&H Department, AITAM, Tekkali, Srikakulam District, Andhra Pradesh.

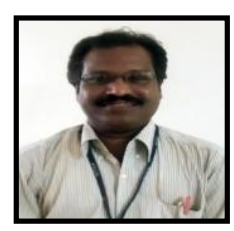

H.Ramamohan: 15 years teaching experience, 03 years industrial experience and 02 years research experience at various levels. At present co-investigator for Major Research Project sponsored by Department of Science \& Technology, New Delhi. At present working as Asst. Professor,
Environmental Studies, B.S.\&H Department, AITAM, Tekkali, Srikakulam District, Andhra Pradesh.

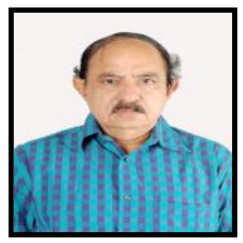

Dr. B.SrinivasaRao: 25 years teaching and 10 years research experience with 15 research papers on "Atmospheric Physics". Acted as Board of Studies member for Under Graduation, Andhra University, Department of Physics. At present working as Professor of Physics, B.S.\&H Department, AITAM, Tekkali, Srikakulam District, Andhra Pradesh. Acting as Board of Studies member for Department of Physics, AITAM, Tekkali 